\title{
Description and Cytology of a Form of Signal Grass (Brachiaria brizantha Stapf.) and its Agronomic Behavior Compared to Guinea Grass (Panicum maximum Jack.) $)^{1}$
}

\author{
A. Sotomayor-Rios, J. Vélez-Fortuño, R. Woodbury, \\ K. F. Schertz, and A. Sierra-Bracero ${ }^{2}$
}

\section{INTRODUCTION}

Signal grass (Brachiaria brizantha), a widely utilized forage crop in the Eastern Hemisphere, is practically unknown in the Western Tropics. It is a perennial grass native to Africa, a form of which, Puerto Rico P.I. No. 1525, was introduced from Ceylon to this Station in 1956.

Bogdan (2) ${ }^{3}$ in East Africa reported that Signal grass is very variable; he also mentioned that several varieties show striking differences in habit, morphology, and seed-setting capacity.

Only this form has been introduced at this Station. During the preliminary evaluation it showed desirable characteristics and potentialities of becoming a valuable forage crop in Puerto Rico. It has proved to be aggressive, competes quite satisfactorily with other species, and quickly covers the ground. It is highly resistant to drought and recovers well from close cuttings. Anker-Lagefoged (1) in Ceylon, reported the outstanding success of Signal grass. He mentioned also that the introduction of this grass has revolutionized the grassland farming there and noted various qualities that make Signal grass unique in Ceylon. A very interesting one of these is that $B$. brizantha grows well under shade. He proposed that this grass should also be planted in coconut lands and in the dry forests.

Observations in field plots $^{4}$ in various regions throughout the Island of Puerto Rico indicate that this grass grows better and yields higher when planted on acid rather than on alkaline soils.

1 Joint Contribution from the Agricultural Experiment Station of the University of Puerto Rico, Río Piedras, P. R., and the Federal Experiment Station, U. S. Department of Agriculture, Mayagüez, P. R. Photos of figures 2, 3, and 4 by Dr. Julio Bird of the Phytopathology and Botany Department, Río Piedras Station.

2 The first three authors are: Research Assistant in Plant Breeding; Head, Department of Plant Breeding; and Taxonomist; Agricultural Experiment Station of the University of Puerto Rico, respectively. The last two authors are: Plant Geneticist, USDA, ARS, Federal Experiment Station, Mayagüez, P. R., and Research Assistant in Agronomy, Agricultural Experiment Station of the University of Puerto Rico at Río Piedras.

${ }^{3}$ Italic numbers in parentheses refer to Literature Cited, p. 220.

${ }^{4}$ Personal communication to the senior author by Dr. L. Rivera Brenes, Head, Animal Husbandry Department, Agricultural Experiment Station. 
The above observations led to more intensive studies, the results of which are presented in this paper. The main objectives of the study were to make a field description, study the cytology of this grass, and compare its agronomic behavior to that of Guinea grass (Panicum maximum).

Guinea grass was selected as the check plant for testing this introduction since it is well known to be one of the most important forage grasses in Puerto Rico and widely used elsewhere in the Tropics. Any forage grass which compares well with Guinea grass can be thought of as a promising forage grass for our tropical conditions, provided its palatability is acceptable.

\section{MATERIALS AND METHODS}

The field description of Signal grass was made from plants obtained from the grass collection established at the Agricultural Experiment Station, Río Piedras, P. R.

Studies of its cytology were undertaken in cooperation with the Federal Experiment Station at Mayagüez, P. R. The chromosome number was determined from root-tip smears in aceto-orcein. Microsporocyte smears were made in aceto-carmine, and pollen was stained in IKI solution.

The agronomic comparison of Signal grass with Guinea grass was carried out at the Gurabo Substation for a period of 530 days. The experiment was conducted on a Mabí clay with a pH of 4.5. The design was a randomizedblock with six replications. Each plot was $10 \times 20$ feet. Both grasses were planted vegetatively.

The experiment was planted on April 22, 1958, and the first cutting was made on June 24, 1958. From there on, the grasses were harvested at approximately every 60 days until October 2,1959 . Weights of green forage were obtained after each harvest. A sample of green forage was taken from each plot at each harvest and analyzed for dry matter and total nitrogen. Samples were composited for the last three cuttings and the composites were analyzed separately for calcium, phosphorus, potassium, magnesium, and liginin.

A total of 380 pounds of nitrogen per acre yearly was applied as ammonium sulfate and applications of phosphorus and potassium were made at rates of 150 pounds of $\mathrm{P}_{2} \mathrm{O}_{5}$ from 20-percent superphosphate and 200 pounds of $\mathrm{K}_{2} \mathrm{O}$ from $\mathrm{KCl}$ per acre yearly, distributed in equal applications after each cutting.

\section{EXPERIMENTAL RESULTS}

FIELD DESCRIPTION OF SIGNAL GRASS

Signal grass is a fast-growing plant having a densely matted growth habit (fig. 1) and flowers throughout the year. The slender creeping stems, which root at the nodes (fig. 2), reach a length of $2 \mathrm{~m}$. or more. 
The ascending linear lanceolate leaves are 10 to $20 \mathrm{~cm}$. long and 1 to 2 $\mathrm{cm}$. broad; the tips are gradually reduced to an accuminate apex, the rounded truncate base is slightly reduced; the margin is serrulate with ascending hispid hairs developed from a narrow white scleroid margin. The blades and sheaths are softly setuloseciliate.

The flowering culm (fig. 3) is glabrous except in the loosely pilose inflorescence containing 2 to 4 distant, usually ascending racemes. The basal

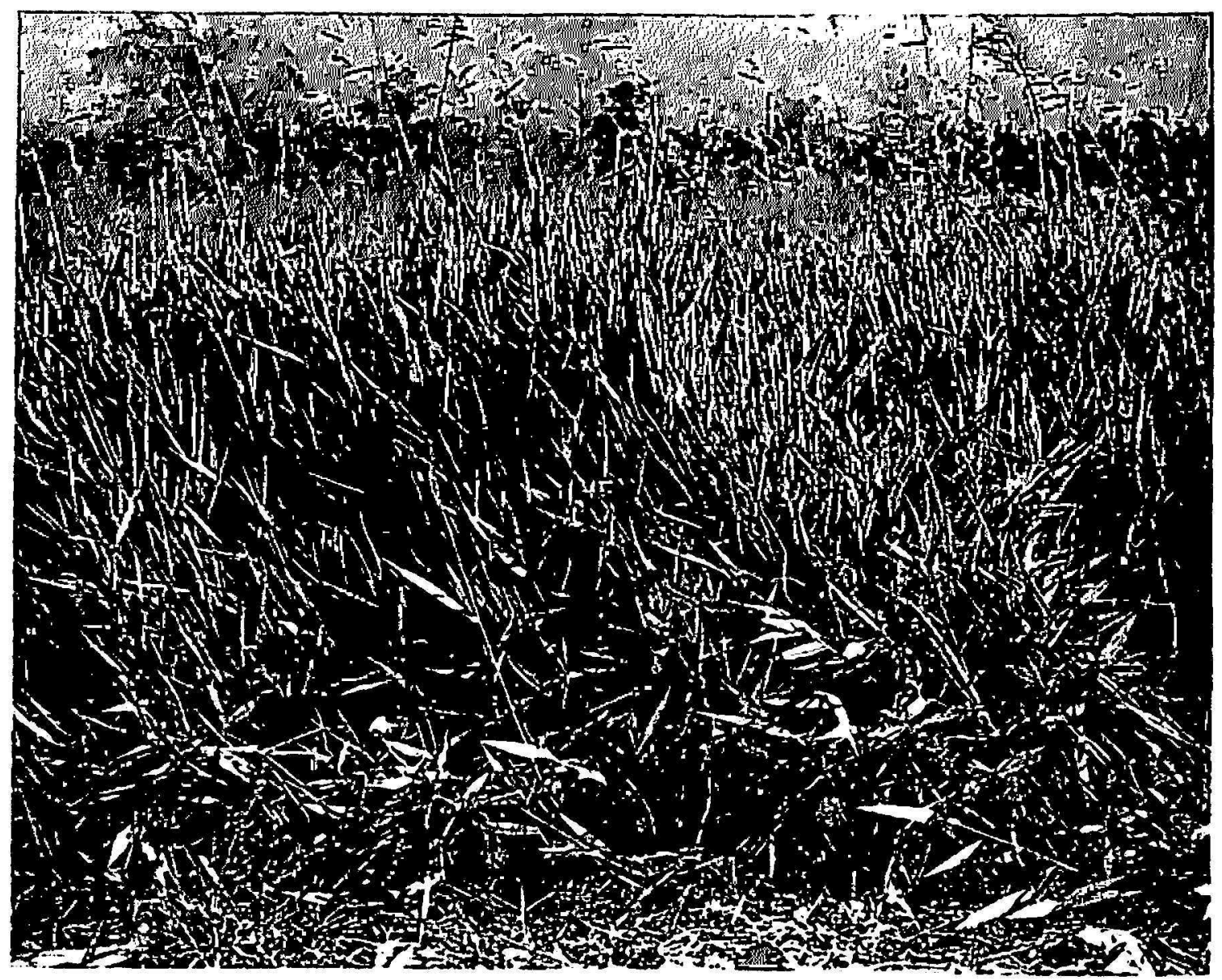

FIG. 1.-A general view of a plot of Signal grass at the Gurabo Substation.

one, however, is sometimes divergent. The culm is terminated by a panicle of two to four, but usually three racemes, one terminal and two lateral, which are slightly reduced in length toward the apex (fig. 3). The lateral racemes have a length of 6 to $10 \mathrm{~cm}$. and contain 20 to 30 spikelets, while the terminal raceme is only 3 to $6 \mathrm{~cm}$. long and contains 16 to 25 spikelets.

The ascending spikelets (fig. 4) which are secundly arranged in two indistinct rows along a rachis are usually paired, elliptic-obovate, and have a length of 5 to $6 \mathrm{~mm}$. and are 1.8 to $2 \mathrm{~mm}$. wide. The rachis is glabrous except along the margins where it is ciliate with setulose hairs.

The first glume is glabrous, $2 \mathrm{~mm}$. long, acute to obtuse, and 9-nerved; 
the second glume is setuloseciliate above the middle, 5 to $5.5 \mathrm{~mm}$. long, acutely purple-tipped, (fig. 4) and 7-nerved; the sterile lemma is glabrous or with a few setuloseciliate hairs near the apex, 5.5 to $6 \mathrm{~mm}$. long, and faintly

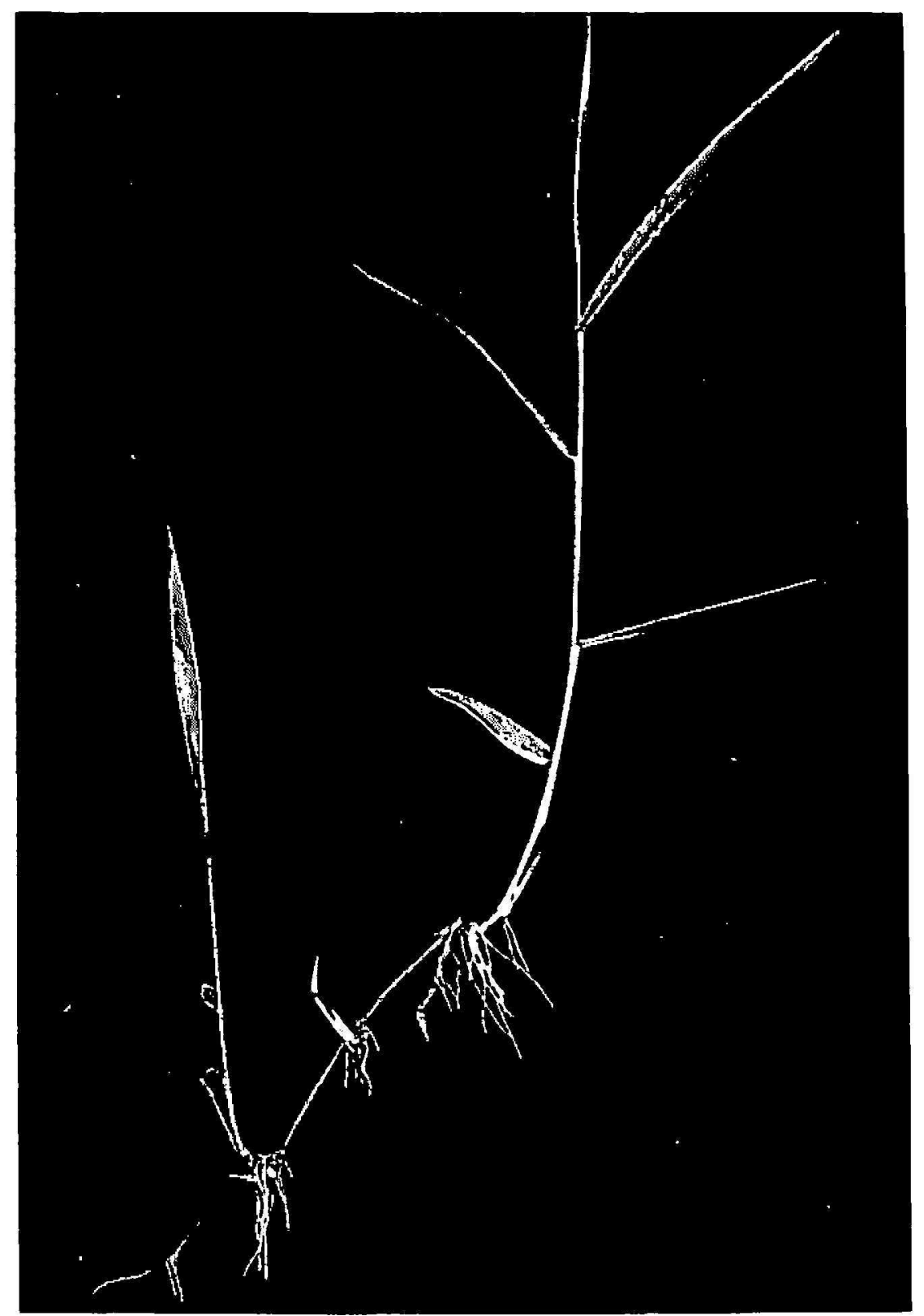

FIG. 2.-A close-up of a plant of Signal grass showing creeping type of stems which root at the nodes.

5-nerved; the indurate fertile lemma and membranous palea are slightly shorter than the spikelet, glabrous, and obtusely acute.

\section{CYTOLOGICAL STUDY}

A study of root-tip smears showed that this introduction had 36 chromosomes (fig. 5A). This number is the same as that reported by Nath and 
Swaminathan (7), but differs from an earlier report of 54 by Moffett and Hurcombe $(6)$.

The literature discloses no information on the breeding and reproductive behavior of Signal grass. Bogdan (3) and Brown and Emery (4) suggested that this grass reproduces apomictically. Bogdan (2) attributed the poor seed production of this grass mainly to the weather conditions at the time of flowering and to diseases and pests. No diseases have been observed in our field plantings. Seed formation was very sparse in our plots of a total of 259 florets examined, only 15 percent developed karyopses.

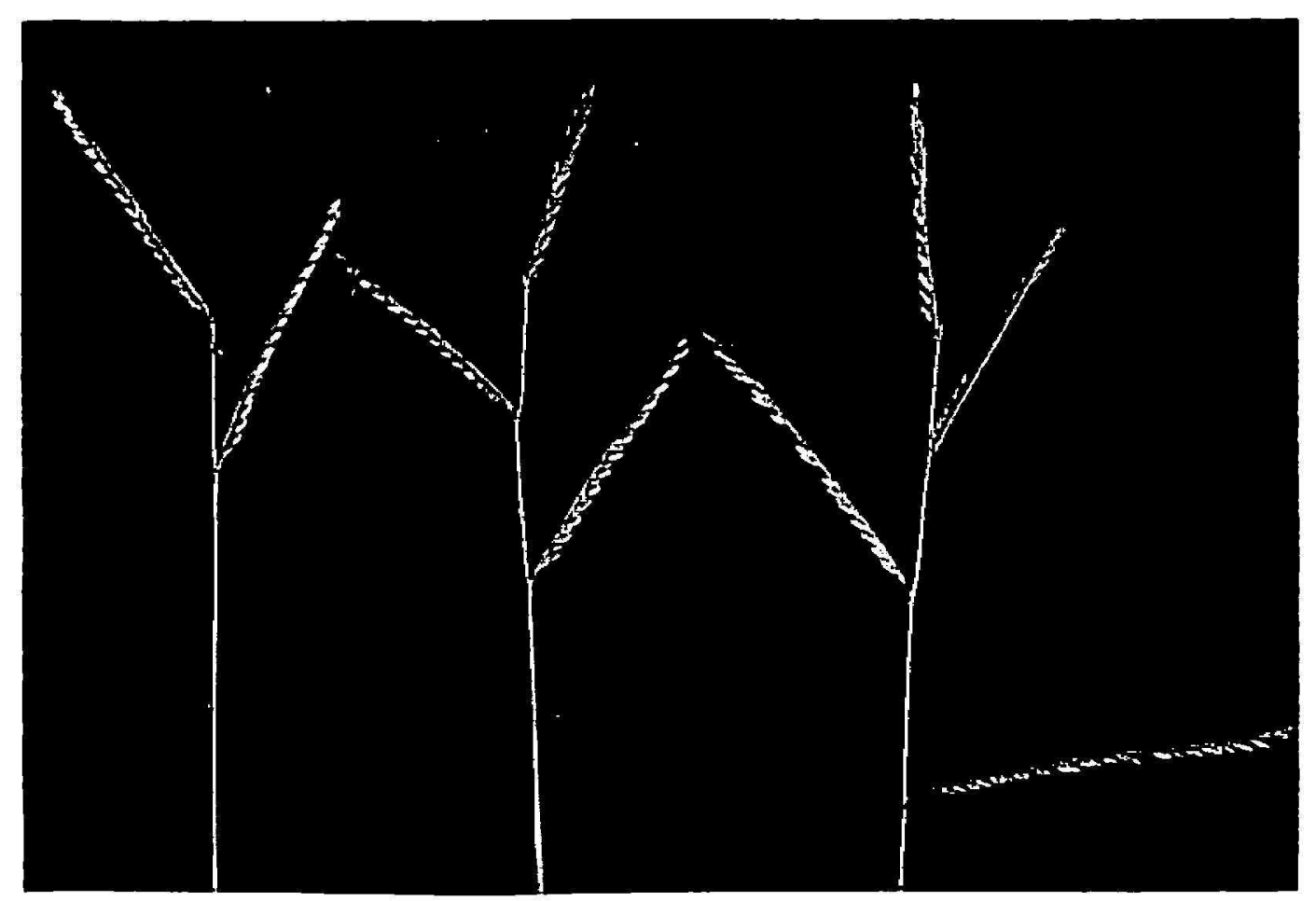

Fig. 3.-A close-up of threc culms of Signal grass showing variation in the number of racemes and hairiness of culms.

When the pollen was stained in IKI solution only 14 percent stained completely. Since meiotic irregularities could have produced the low percentage of viable pollen obtained, a study of microsporogenesis was undertaken. Meiosis in microsporocytes was irregular. Lagging univalents were observed in 69 percent of the anaphase I cells (fig. 5B). The laggards divided and often formed micronuclei (fig. $5 \mathrm{C}$ ). The mean number of micronuclei per spore quartet was two, and only 16 percent of the spore quartets appeared normal.

\section{AGRONOMIC COMPARISON}

The total yields per acre and protein contents of Signal and Guinea grasses during each cutting are presented in table 1 . The data show variations on 


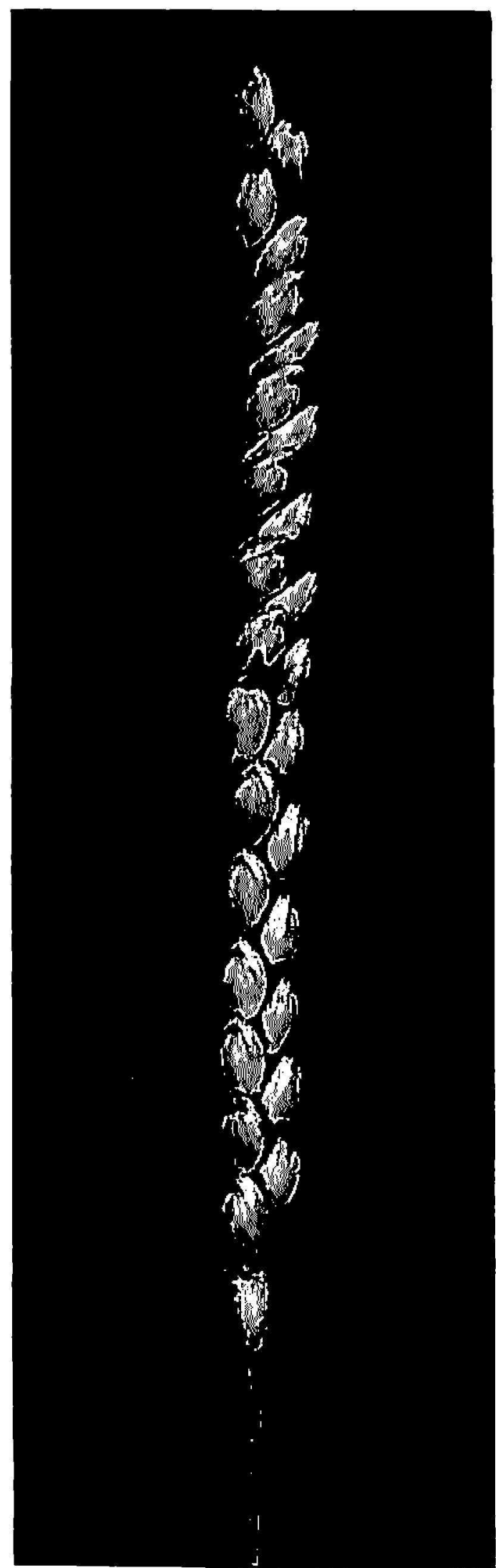

Fig. 4.-A close-up of a raceme of Signal grass showing the purple apex of the second glume and the secund arrangement of spikelets. 
the part of both grasses for the various periods when they were harvested at approximately 60 days. Both grasses made their lowest production during the harvest made in April.

The annual production per acre of Signal and Guinea grasses at the Gurabo Substation is presented in table 2. No significant differences in yield were observed between the two species. The mineral content of Signal grass

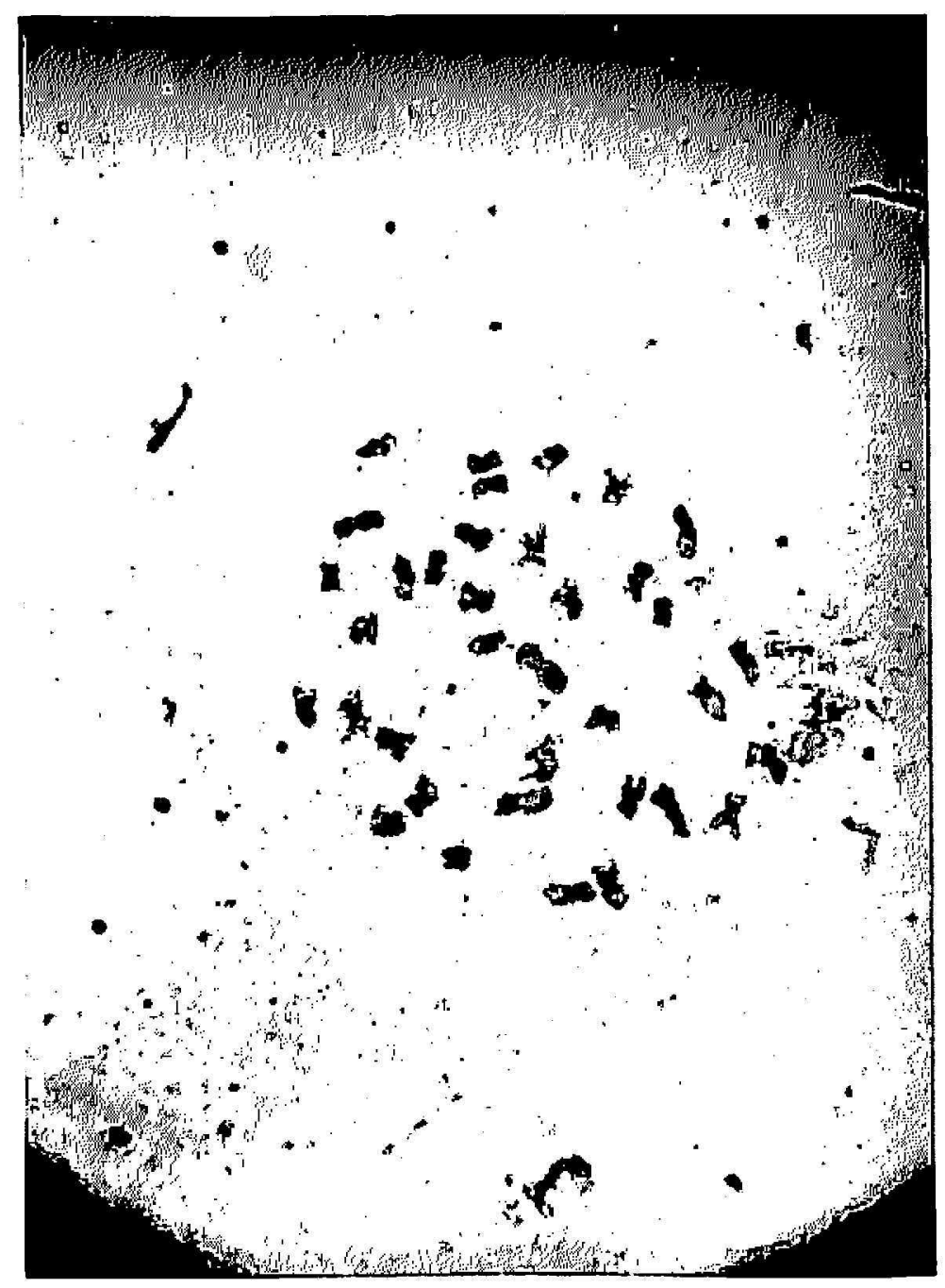

FIG. 5.-A, A smeared root-tip cell of Signal grass with 36 chromosomes; B, lagging univalents at anaphase I; C, microspore quartet with micronuclei. See p. 215 for $\mathrm{B}$ and $\mathrm{C}$.

compared favorably with that of Guinea grass in this experiment, except that calcium and magnesium were definitely higher in Guinea grass (table 3 ). Vicente Chandler et al. (8) found that the calcium content of Guinea grass was also higher than that of Napier grass (Pennisetum purpureum) and Pará grass (Panicum purpurascens).

The data in table 3 show the mineral and lignin content of Guinea and Signal grasses under the conditions of this experiment. All values are composites of six replications and are averages for the last three cuttings. 


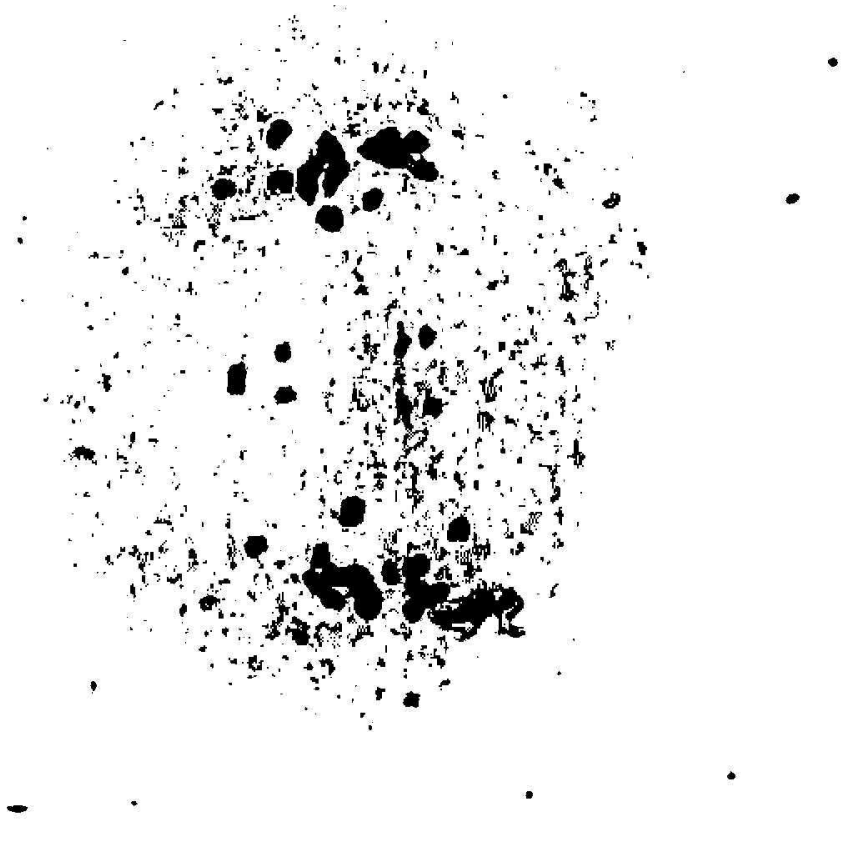

FIG. 5B

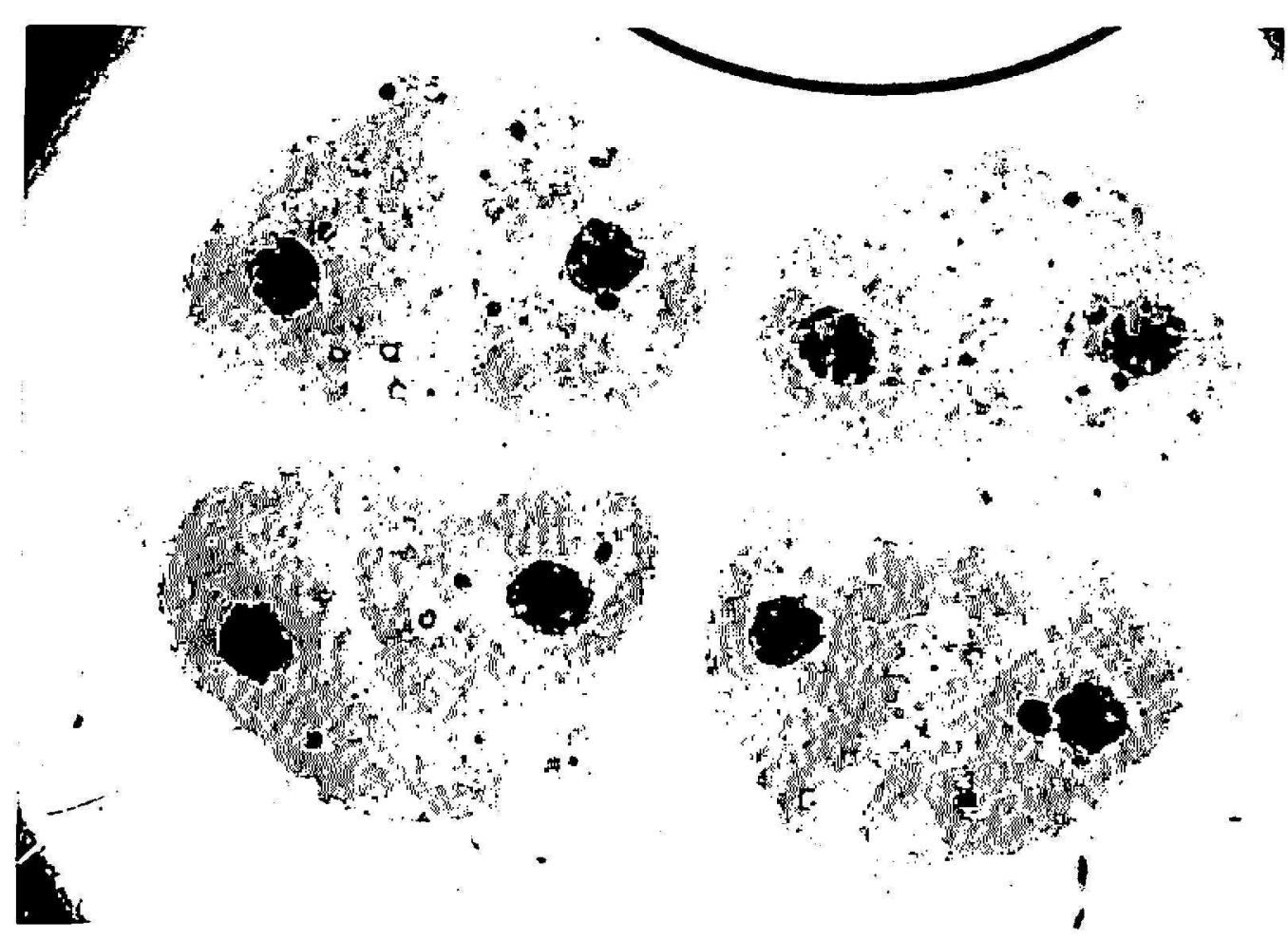

Fig. 5C 
TABLE 1.-Yields and protein contents of Signal and Guinea grasses for each cutting during the 530-day period at the Gurabo Substation

\begin{tabular}{|c|c|c|c|c|c|c|c|c|c|}
\hline \multirow{2}{*}{$\begin{array}{l}\text { Cutting } \\
\text { No. }\end{array}$} & \multirow[b]{2}{*}{ Date } & \multicolumn{4}{|c|}{ Signal grass } & \multicolumn{4}{|c|}{ Guinea Grass } \\
\hline & & $\begin{array}{l}\text { Yields, } \\
\text { green } \\
\text { forage }\end{array}$ & $\begin{array}{l}\text { Yields, } \\
\text { dry } \\
\text { matter }\end{array}$ & Protein & $\begin{array}{r}\text { Protein } \\
\text { yields }\end{array}$ & $\begin{array}{l}\text { Yiclds, } \\
\text { green } \\
\text { forage }\end{array}$ & $\begin{array}{c}\text { Yields, } \\
\text { dry } \\
\text { matter }\end{array}$ & Protein & $\begin{array}{c}\text { Protein } \\
\text { yields }\end{array}$ \\
\hline & & $L b . / A$. & $L b . / A$. & Percent & $L b . / A$. & $L b . / A$. & $L b . / A$. & Percenl & $L b . / A$. \\
\hline 1 & June 24,58 & 13,242 & 3,681 & 6.72 & 247 & 16,727 & 4,487 & 7.13 & 320 \\
\hline 2 & Aug. 21, 58 & 15,377 & 4,312 & 10.35 & 446 & 16,183 & 4,356 & 8.65 & 377 \\
\hline 3 & Oct. 11,58 & 9,365 & 1,732 & 14.01 & 243 & 6,316 & 1,106 & 17.12 & 189 \\
\hline 4 & Dec. 10,58 & 11,565 & 2,544 & 10.89 & 277 & 9,540 & 2,121 & 14.91 & 316 \\
\hline 5 & Feb. 8,59 & 19,602 & 5,336 & 12.16 & 649 & 9,910 & 2,204 & 14.84 & 329 \\
\hline 6 & Apr. 8, 59 & 2,679 & 980 & 7.93 & 78 & 5,009 & 1,657 & 8.74 & 145 \\
\hline 7 & June 5,59 & 31,429 & 7,209 & 12.60 & 308 & 34,042 & 9,017 & 12.76 & 1,150 \\
\hline 8 & Aug. 3,59 & 15,311 & 4,835 & 10.62 & 513 & 17,446 & 5,249 & 11.60 & 609 \\
\hline 9 & Oct. 2,59 & 29,033 & 7,579 & 9.25 & 701 & 32,191 & 8,037 & 9.43 & 758 \\
\hline \multicolumn{2}{|c|}{ Total } & 147,603 & 38,208 & & 4,062 & 147,364 & 38,234 & & 4,193 \\
\hline
\end{tabular}

TABLE 2.-Annual acre-yields and crude-protein contents of Signal and Guinea grasses when grown at the Gurabo Substation for a period of 580 days

\begin{tabular}{c|c|c|c|c}
\hline \multicolumn{1}{c|}{ Species } & $\begin{array}{c}\text { Yield of green forage } \\
\text { per acre yearly }\end{array}$ & $\begin{array}{c}\text { Yield of dry matter } \\
\text { per acre yearly }\end{array}$ & $\begin{array}{c}\text { Crude-protein } \\
\text { content }\end{array}$ & $\begin{array}{c}\text { Crude-protein yield } \\
\text { per acre yearly }\end{array}$ \\
\hline Signal grass & $L b$. & $L b$. & Percent & $L b$. \\
Guinea grass & 08,598 & 25,523 & 10.63 & 2,713 \\
\hline
\end{tabular}

TABLE 3.-Comparison of the mineral and lignin contents of Signal and Guinea grasses as grown at the Gurabo Substation and harvested approximately every 60 days

\begin{tabular}{l|c|c}
\hline Component & Signal grass & Guinea grass \\
\cline { 2 - 3 } Phosphorus & Percent & Percent \\
Potassium & 0.14 & 0.09 \\
Calcium & 1.12 & 1.12 \\
Magnesium & .24 & .55 \\
Lignin & .65 & .84 \\
& 7.42 & 8.55 \\
\hline
\end{tabular}

The lignin content of Signal grass was 7.42 percent, whereas it was 8.55 for Guinea grass. The small difference in lignin content which favors Signal grass may indicate more in terms of animal digestibility, than in those of the chemical analysis. 


\section{EFFECT OF THE SEASON OF THE YEAR}

It is well-known that forage production decreases during the dry months. Vicente Chandler et al. (8) reported that the season of the year had a marked effect on forage production largely as a result of rainfall.

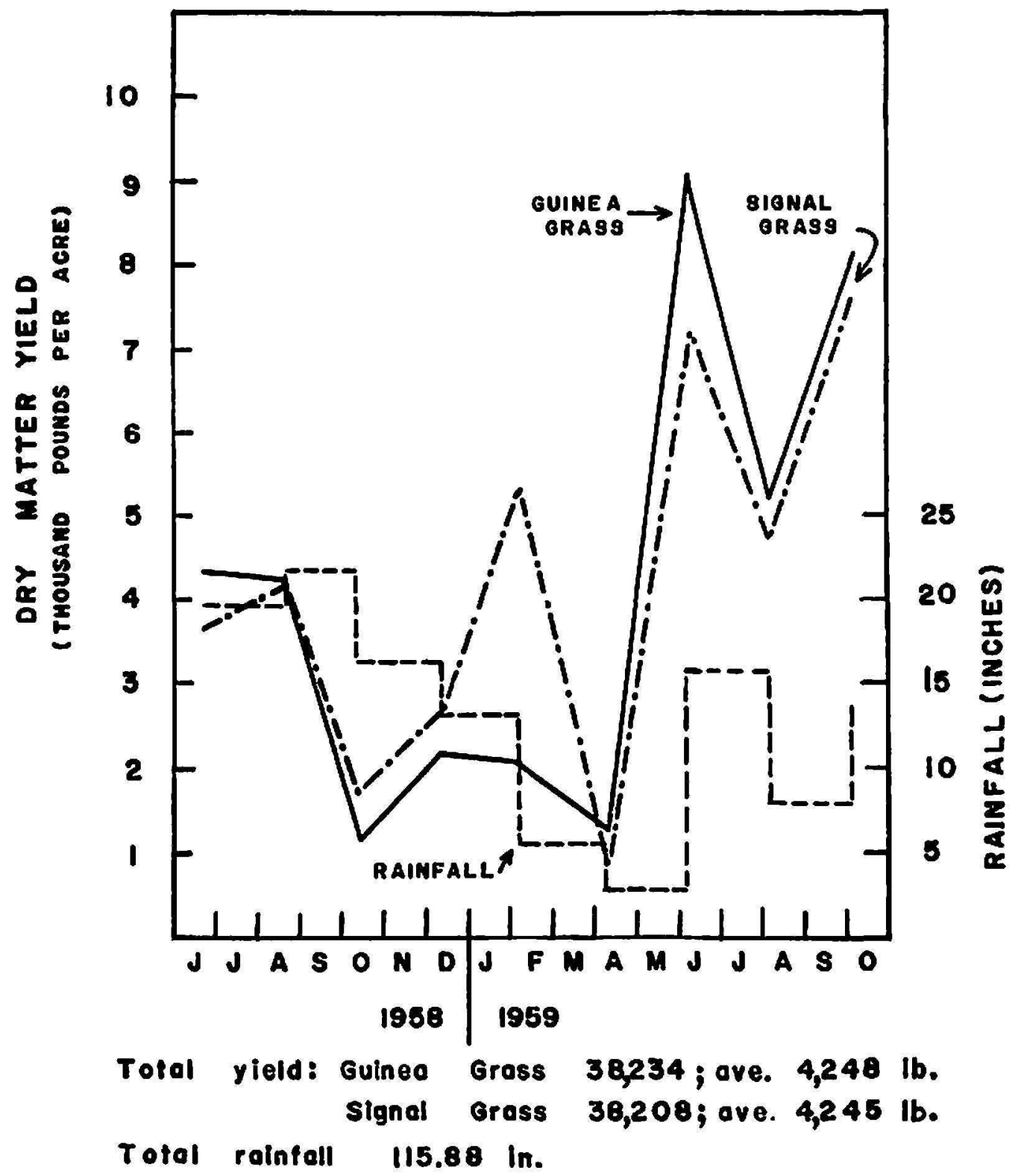

Fig. 6.-Effect of the season of the year and rainfall on yields of Guinea and Signal grasses cut approximately every 60 days at the Gurabo Substation.

Figure 6 shows the effect of the season and rainfall during the growing period on the forage production of Signal and Guinea grasses. Signal grass seemed to be less affected during the dry months, from October to April, than Guinea grass. It appears that Signal grass is more drought-resistant than Guinea grass, although, in order to arrive at more definite conclusions, more research is desirable. 


\section{DISCUSSION}

Various workers have indicated that, in general, there is a wide variation in Signal grass (B. brizantha) especially in its habit of growth, which shows varying degrees of creeping to erectness and bunchiness of stems. The number and size of racemes, pubescence of stems, leaves, and inflorescence are also quite variable in the different forms.

The somatic chromosome number of this form of Signal grass was found to be 36 . Chromosome numbers of 54 and 36 are reported in the literature $(6,7)$. This variation in chromosome number, and also the fact that other workers in East Africa reported that there exist many forms of Signal grass, indicates that further cytological studies may turn up more variation in chromosome number.

Only 15 percent of the florets examined developed karyopses. Although Bogdan (2) attributed the poor seed production of Signal grass mainly to the weather conditions at the time of flowering, and to diseases and pests, it appears that the degree of abnormal behavior of chromosomes from the observations at microsporogenesis noted is a contributing factor of great importance in the low seed-set obtained on this form.

When Signal grass was compared to Guinea grass at the Gurabo Substation, and both grasses were harvested at approximately 60-day intervals, they both produced about 49 tons of green forage per acre yearly. This amount (about 13 tons of dry matter) is sufficient to satisfy the forage requirements of about 3.5 mature cows or steers, assuming a daily consumption of 20 pounds of dry matter per day per animal. Higher yields can be obtained comparable with those secured from Guinea grass by other workers under higher fertilization and proper management.

The slightly variable mineral content of the two grasses under this experiment seemed to be of little significance. The calcium and magnesium contents of Signal grass were apparently lower than those of Guinea grass. The phosphorus and potassium contents were almost the same for the two grasses under study. There was a small difference in favor of Signal grass in regard to the lignin content.

Under the growing conditions prevalent at the Gurabo Substation during the course of the experiment herein reported Signal grass was apparently more drought-resistant than Guinea grass.

\section{SUMMARY}

The somatic chromosome number of a form of Signal grass (Brachiaria brizantha Stapf.), Puerto Rico P.I. No. 1525, introduced from Ceylon, was found to be 36 . Only 15 percent of the florets studied developed karyopses. The meiotic behavior of chromosomes at microsporogenesis was irregular. Frequent lagging univalents at anaphase 1 and micronuclei in the spore quartets may account for the low seed-set of this form. More improvement 
of this character is expected in Signal grass through further research in genetics and by the introduction of more forms and varieties.

A field description of Signal grass is given. Signal grass was compared to Guinea grass (Panicum maximum Jack.) as to agronomic behavior. It showed desirable characteristics, besides yielding the same as Guinea grass, one of our best forage grasses, when both grasses were tested at the Gurabo Substation for a period of 530 days.

The mineral content of the grasses under this experiment was comparable, but calcium and magnesium were definitely higher in Guinea grass. The lignin content of Signal grass was lower than that of Guinea grass; this difference, although small in favor of Signal grass, may have more importance in terms of animal digestibility than the chemical analyses indicate.

The results obtained in relation to yielding ability and drought-resistance of this form of Signal grass are very encouraging. As the palatability of this grass has been found to be comparable to that of Napier grass ${ }^{5}$, which is the standard grass used for palatability tests at this Station, it may be expected to occupy in due time a very important place as a forage crop throughout the Island of Puerto Rico, especially in the drought areas.

\section{RESUMEN}

Se encontró que el número somático de cromosomas de una forma de la yerba Signal, (Brachiara brizantha Stapf), Puerto Rico P.I. No. 1525, importada de Ceylán, es de 36 . Solo el 15 por ciento de las florecillas estudiadas desarrollaron cariopsis. El comportamiento meiótico de cromosomas durante la microsporogénesis fué irregular. Frecuentes univalentes retardados en la anafase 1 y micronúcleos en los cuartetos de esporas, puede que tengan que ver con la escasa semilla que se produce. Un mejoramiento de este caracter de la yerba Signal se espera lograr por medio de más estudios genéticos y por la introducción de más formas y variedades de esta yerba.

Se hizo una descripción de campo de la yerba Signal. Esta yerba se comparó con la yerba de Guinea, (Panicum maximum Jack), en cuanto a su comportamiento agronómico. Demostró tener caracteres deseables y rendimientos similares a los de la yerba de Guinea, que es una de nuestras mejores yerbas forrajeras, en un experimento llevado a cabo en la Subestación de Gurabo, el cual duró 530 días.

El contenido mineral fué comparable en ambas yerbas, excepto en cuanto a calcio y magnesio, los cuales fueron definitivamente más altos en la yerba de Guinea. El contenido de lignina fué más bajo que en la yerba de Guinea. Esta diferencia, aunque pequeña y a favor de la yerba Signal, puede ser de más importancia en términos de digestibilidad animal que lo que los análisis químicos indican.

Los resultados obtenidos en relación a los rendimientos y resistencia a la

${ }^{6}$ The Animal Husbandry Department of the Agricultural Experiment Station. 
sequía son halagadores. Si esta yerba resulta ser de buena palatabilidad, podría ocupar un sitio destacado como yerba forrajera para todo Puerto Rico y especialmente, para aquellas áreas que sufren de sequías peródicas.

\section{LITERATURE CITED}

1. Anker-Lagefoged, A. V., The role of gasssland in Ceylon's agriculture, Trop. Agr. 111 (4) 257-66 1955.

2. Bogdan, A. V., Herbage plants at the Grassland Research Station, Kitale, Kenya, E. Afr. Agr. J. 20 (3) 151-65, 1955.

3. - The selection of Tropical Ley grasses in Kenya: General considerations and methods, E. Afr. Agr. J. 24 (3) 206-17, 1959.

4. Brown, W. V., and Emery, W. H. P., Some South African apomictic grasses, $J$. of S. Afr. Bot. 23 (4) 123-5, 1957.

5. Horell, C. R., Herbage plants at Serere Experiment Station, Uganda 1954-1957-1: Grasses, E. Afr. Agr. J. 24 (1) 41-6, 1958.

6. Moffett, A. A., and Hurcombe, R., Chromosome numbers of South African grasses, Hered. 3 369-73, 1949.

7. Nath, J. and Swaminathan, M. S., Chromosome numbers of some grasses, Ind. J. Gen. and P. Breeding 171021957.

8. Vicente-Chandler, J., Silva, S. and Figarella, J., The effect of nitrogen fertilization and frequency of cutting on the yield and composition of three tropical grasses, Agr.J. 51 (4) 202-6, 1959. 